\title{
TEACHING SUPERVION OF MADRASAH HEADMASTER BASED ON PESANTREN CULTURE
}

\author{
Nadhirin \\ STAIN Kudus, Central Java, Indonesia \\ nadhirin072@gmail.com
}

\begin{abstract}
To realize the learning, it takes teaching supervision activities. The target of supervision is the teaching staff. The purpose of this paper is to find out (1) how the teaching supervision activities in madrasah is (2) how the techniques and approaches of supervision is (3) how the supervision of teaching in the madrasah is based on pesantren culture. The research method is library research with the technique of collecting the source of supervision theory of teaching through literature study and analysis technique with deductive-inductive thinking pattern. The results showed that (1) supervision of teaching in madarash is a function of leadership communication with pesantren culture so the relationship between teachers with the headmaster or between teachers and students is to follow the pattern of relationship between kyai and santri (2) supervision approaches with a limited personal relationship approach and in an informal setting are much more effective because supervisory activities between teacher and headmaster are not open (3) teaching supervision uses cultural organization group of religion technique (4) teaching supervision uses situational integrated approach.
\end{abstract}

Keywords: Teaching, supervision, pesantren

\section{A. Introduction}

Quality of education in Indonesia seen from the perspective of teaching resources still needs continuous improvement so that the education output in Indonesia can meet the demands of human resources in the era of global competition. Some indications of low quality of education in Indonesia can be seen from the evaluation report from AAEI (Association for Evaluation of Educational Achievement International). This institute conducts an evaluation of the mastery of science to students internationally followed by 
50 participating countries. As a result, Indonesian students are in the order of 36 under Egypt and Palestine. While our neighboring countries, Singapore and Malaysia still occupy the number one and number twenty. In 2008, UNDP released its report on the condition of HDI (Human Development Indiks). In the report, Indonesia was ranked on 108 th out of 177 countries. This position is still too far if it is compared to the position of our neighboring countries like Malaysia in 59th rank while Thailand in 73rd rank and Philippines in $83^{\text {rd }}$ rank. For Southeast Asian countries, Indonesia occupies one level above Vietnam, a country just out of a big conflict and just started to improve itself but it has shown encouraging achievement because of the great determination to move forward.

Phenomenon above shows that the quality of education in Indonesia is still very far from expectation. The realization of quality education, international standards and being able to compete internationally requires hard work and cooperation from all components. They are from the society, government and education practitioners. One of the most strategic components for immediate and urgent to be addressed is the teacher. In general, teacher professionalism in Indonesia is still far from being expected. Without a professional teacher, it seems difficult to realize the ideals of advanced education and competitive in the global market.

Teachers' professionalism is a necessity if we want to develop the education. Many components of a person to be able to work professionally, including the minimum standard of teacher education, training and opportunities for further study of teachers, salary and allowances are appropriate as a salary allowance given to other professionals such as doctors, lawyers, consultants and other professionals.

Fundamental goal of supervision activities is a quality learning system. The supervision process is a communicative activity between the supervisor and the supervised teacher in finding things that hamper the learning process and then seek the 
best solution in process gradually and continuously so that the learning objectives of the material understanding by the learners can be reached maximally. In addition to the purpose of improving the learning process, supervision also aims at curriculum development tools. The effectiveness of curriculum development along with its technical design is highly dependent on whether or not supervision is functioning. While the nature of the curriculum from time to time is always changing in accordance with the development of science and technology along with changes in society lifestyle. A good supervision run will automatically have a positive impact on the career development of each teaching staff. Schools that are consistent with the task of supervision will quickly advance and develop.

The achievement of supervision purpose depends on the technical implementation of educational supervision. During the review of the supervision model, it refers to the conduct of supervision in American schools. The matters is whether the model of supervision by schools in America is applicable in other schools, including Indonesia. Because the implementation of supervision covers communication activity, the components present in the communication are seen as a unity within the communication system consisting of supervisor, the supervised teacher, the message or the supervision material and the value system affecting the supervision process. This means that the supervisory activities undertaken in the school are influenced by the values that underlie the communication activities in schools. The value system underlying communication lies within a particular cultural context. With this assumption, every school has culture that is not the same. Because of this, an education expert, Prof. Dr. Madyo Ekosusilo, M.Pd conducts research on the implementation of supervision in schools with cultural Javanese background. Because of the technical problem of supervision, there is an idea to find a model that is in accordance with the implementation of teaching supervision in Madrasah Aliyah that 
has pesantren culture. It will be very different in some ways in carrying out this supervision.

Madrasah Aliyah is a formal education institution in which it organizes a teaching system in which there are learning activities. This learning activity requires standardization, competence and curriculum. To get the maximum learning objectives, it needs supervision education function. Madarasah Aliyah with background of pesantren culture has a foundation of norms and values in daily communication activities, both communication in the context of learning and social different from the pattern of commission in society and school in general. This raises a question, what the approach, technique and model of teaching supervision are in Madrasah Aliyah based on Pesantren culture

\section{B. Discussion}

\section{Education Supervision}

According to Peter F. Oliva in Sahertian (2000: 18), educational supervision is anything that school personnel can do to maintain or change what the school does in a way that directly affects the teaching and learning process in an effort to improve student learning. Sagala (2000: 230) understands the supervision of education as a supported service provided to teachers in carrying out teaching tasks so that teachers can help students learn to be better than before. Meanwhile, according to Sutisna in Arikunto (2004: 11) explains that supervision is everything from appointed school officials directed to provide leadership for teachers and other education personnels in improving teaching, seeing the stimulation of professional growth and development of the teachers, selection and revisions of such aims, teaching materials, teaching methods and evaluation of teaching. Daryanto (1998: 175) explains that supervision is the assistance given to educational personnel to develop better educational processes and efforts to improve the quality of education through activities (1) convey ideas, procedures and materials to assess and develop the curriculum (2) developing guidelines, directions, ways and other 
materials to carry out the curriculum; (3) planning improvements in teaching and learning methods formally through upgrading, workshops, seminars, workshops, discussions and official visits; (4) fostering and developing professional organizations such as; MGMP, Kelompok Kerja Guru (KKK), Kelompok Kerja Kepala Sekolah (K3S), Kelompok Kerja Sekolah (KKPS) (5) fostering, guiding and directing teachers to improve knowledge, abilities and skills in carrying out the learning process and (6) studying curriculum, infrastructure, procedures based on educational objectives.

From the various definitions of education supervision above can be concluded that supervision is a service of guidance activities given to the teachers in carrying out teaching tasks through a procedure, approach, technique in a planned, programmed, continuous and continuous aims to improve the quality of learning so that learners get the maximum potential development which at the end is to prepare a superior human resources and highly competitive.

\section{Purpose of educational supervision}

Olive in Sahertian (2000: 19) mentions that the purposes of supervision are (1) developing curriculum that is being implemented in school (2) improving teaching and learning process in school (3) developing all staffs in school. Daryanto (1998: 172-174) explains that the purposes of supervision are to (1) provide guidance to teachers in order to improve their ability to understand and implement a curriculum that tends to change in accordance with changes and demands (2) develop personnel, employees, or employees at school. Sagala (2000: 235) explains that the purposes of supervision are to (1) assist teachers in developing teaching and learning process (2) assist teachers in translating curriculum into language learning and (3) assisting staff development.

From some objectives that have been formulated above can be concluded that the purpose of supervision is the development 
of the curriculum, improve the process of effective learning and develop all staffs in school.

\section{Principles of Education Supervision}

Supervision is an institutional activity that involves many people in this activity. In carrying out these tasks and supervisory functions should be grounded in the basic principles that are firm and consistent in the improvement of learning and maintaining and maintaining good relationships among faculty and management. Sahertian (2000: 20) completes four principles underlying supervision activities:

1) Scientific principle, this principle requires an objective, data-based, planned and procedure-driven and continuous work, so that problems that occur in the learning process can be fixed and experienced continuous improvement so that the purpose of effective and quality learning can be materialized.

2) Democratic principles, this principle requires that supervision activities carried out in an atmosphere of intimate relationships that are based on high self-esteem and dignity of teachers by not dropping each other. The relationship between the persons supervising the supervised teacher is not structural, non-supervisory and subordinate but supervision should be done based on peer relationships.

3) Principle of cooperation, i.e. supervision activities based on the principle of developing a joint business or in terms of supervision is sharing of ideas, sharing of experience, giving support of encouraging and stimulating teachers, so they feel growing together.

4) Constructive and creative principles, i.e. supervisory activities by which teachers become motivated in teaching and able to create a pleasant working atmosphere rather than through frightening working methods. 
Sutisna (1983: 224) identifies nine principles of supervisory activity, namely:

1) Supervision is an integral part of the education program, it is a cooperative service

2) all teachers are entitled to a supervision service

3) supervision should be adapted to meet the individual needs of school personnels

4) supervision should help clarifying educational goals and objectives

5) supervision should help the improvement of the attitudes and relationships of all school staff as well as supervision aimed at creating relationships between school and community closer to each other

6) the responsibility for supervision development lies with the principal and the overseers or supervisors in the region

7) there should be sufficient funds in implementing this supervision program and incorporated into the annual budget

8) the effectiveness of the supervision program should get an administrative report

9) supervision should help to clarify and apply the current practice of educational research findings.

From some basic principles that underlie the supervision program, it can be concluded that supervision is basically a leadership function in school. So the basic principles of supervision in the perspective of school leadership are the development of the potential and ability to carry out teaching tasks and create an atmosphere of working relationships that are conducive, fun, cooperative from all staff works in the school. The basic principle of supervision should get full support from the school administration and management system, if there is no cooperation then the supervision will be ineffective because not all teachers assessed as effective yet are willing to be given guidance. 


\section{Supervision Model}

The meaning of the supervision model is the pattern or reference of the applied supervision. Sahertian (2000: 4) divides the model in the implementation of supervision to four models, namely:

1) conventional model. This conventional model is related to the development of the culture of society. School institutions located in communities still apply feudal, authoritarian and instructive culture, and then the implementation of supervision at the school is conventional. This supervision model is understood as an inspection or looking for errors of the teachers and then provide condite.

2) scientific supervision model. This scientific model has characteristics, namely the problems encountered in the learning process based on data, using procedures and terrana

3) model of clinical supervision. The underlying feature of clinical supervision when compared to other models is that supervision focuses on teachers who are having a serious problem in teaching practice. So the purpose of the supervision of this model is to minimize the gap between the performances of the teacher in teaching with the appearance of teaching that should be.

4) artistic model. The model of artistic supervision is based on an assumption that the worker teaches in addition to being an educator and a skill, teaching can also be viewed as an art. Teaching is placed as an art, placing the teacher as a person entitled to differ in style of teaching. This difference should be understood by the person who supervises so that the implementation of supervision with this model requires a relationship between the teacher and the person supervising in humanitarian, natural, and communicative relationships.

The supervisory models above are not stand-alone but complementary to each other, only in appearance there is one 
model that dominates and adapts to the school and personal context of each supervisor and supervised teacherPendekatan dalam supervisi

\section{a. Approaches in supervision}

Glickman in Sahertianen $(2000 ; 44)$ explains that the approach used in supervision is based on psychological principles. There are three approaches in educational supervision, namely (1) directive approach (directive approach). Supervision with a directive approach places the supervisor directly into trouble. Supervisors may use reinforcement or punishment. This direct approach is based on behaviouristic psychology, in which human behavior follows or responds to the stimulation that exists outside of itself. (2) Indirect approach (indirective approach) is approach to some indirect issues. A supervisor doesnot on directly show some problems faced by teachers, but teachers were told deliver problems faced when doing the teaching. This approach is based on the theory of humanistic psychology. (3) Collaborative approach. This approach aggregates between directive and nondirective approaches. In this approach, both the supervisor and the teachers sit in a room together, then discuss the problems encountered and then define structure, criteria and procedures in implementing the supervision program. This collaborative approach is based on the theory of cognitive psychology; a theory that looks at human behavior as a combination of personal behavior and environmental behavior around it (Sahertian, 2000: 51).

\section{b. Educational supervision techniques}

According to Sutisna (1983: 226), there are ten techniques in the supervision of education: (1) the classroom (2) individual talks (3) group discussions (4) teaching demonstrations (5) classroom visits among teachers (6) curriculum development (7) supervision bulletins (8) professional libraries (9) workshops and (10) community school surveys. Meanwhile, according to Gwyn (1963) in Sahertian explains that there are six techniques in 
supervision, namely; (1) class visit (2) class observation (3) private conversation (4) inter-visitation (5) selecting various material resources for teaching and (6) self-assessment. Arikunto (2004: 54-55) groups supervision techniques based on individuals and groups. The individual-based supervision technique consists of four techniques, namely; (1) class visits (2) classroom observation (3) individual interviews and (4) group interviews. While group supervision techniques consist of (1) meeting (2) holding group discussion (3) holding upgrading and (4) seminar.

From the various techniques presented above, it can be understood that the supervision technique is situational, which is highly dependent on the site, the character of each teacher and the nature of the learning problems being faced. With this perspective, the supervision technique's reference as mentioned above can be applied by the supervisor depending on the encounter that surrounds the problem.

\section{Integrative Supervision}

Education is an activity that deliberately and planned to transform science, technology, art and value so that there is expectation of learners attitude and behaviour change. This educational process changes over time. These changes concern the curriculum content and design, learning technology, technology and shifts in values and culture due to global change. These changes bring consequences in the world of education. Therefore, education practitioners must adapt to those changes. Master is the leading character in education. Because of that, the function and role of supervision cannot be avoided as a special service activity given to the teaching staff so that the teachers can play their role professionally. Teachers who are difficult to adapt to changes are understood as teachers who need to get supervision guidance services. An educational institution whose teachers do not get the opportunity to obtain supervision services is an institution that is not ready yet to compete in quality. 
Service supervision activities are not easy activities. Teaching Supervision requires good planning, proper implementation model and more importantly is the supervision of teaching in accordance with the setting and culture in which the institution carries out the teaching process. Each institution has a model of supervision that does not have to be the same. Effective techniques and approaches applied to an institution do not guarantee the effectiveness of engineering and supervision approaches in other educational institutions. Starting from the above assumptions, then the supervision of teaching should be adapted to the institution's character, the character of the problem and the character of the supervised teacher.

Thomas J. Sergiovani, an American education expert, gives concentration to teaching supervision. According to him, there are many supervision applied in various schools. The supervisory model is about approach and supervision techniques. In the practice of educational supervision in several approaches known, namely the scientific approach, clinical approach and artistic approach. The three approaches are derived from the underlying concepts and theories. The scientific approach derives the theory that teaching is an academic process that has a planning, process and mechanism of learning and evaluation that emphasizes the standards, the process of collecting data objectively and the teaching norms. The approach of clinical supervision is derived from the concepts and theories that an ineffective teaching process performed by a teacher is considered as a mistake or disease. To correct the ineffectiveness, a supervisor performs a diagnosis as well as diagnosing a disease that is interfering with human health. The approach of artistic supervision in teaching is derived from the concept and theory that teachers who do the teaching process are a human whose complex dimension. In the artistic supervision approach, human beings are not only viewed as academic human beings but human beings have human dimensions. They are such as that teachers are entitled to have a teaching style that is not necessarily the same as other teachers, teachers are entitled to 
honourable treatment, teachers are entitled to obtain training and professional development and each teacher is a person with different social and experiential backgrounds.

In the history of its knowledge, the approaches and techniques employed in the practice of supervision are not concurrent and are not derived from a single scientist. Nevertheless, they appear in the dialectical history of the science of education which is always evolving in different socio-cultural settings and in the context always changing. The three concepts and theories of supervision practice are scientific, clinical and artistic. According to Sergiovani's view, they are integrated, not mutually exclusive but complemented in understanding the teacher's dimensions.

In the study of this intergalactic supervision, Sergiovani argues that supervision will be able to develop if teaching is seen as one side as a science. And on the other hand, teaching is an art that is loaded with value content. Academic teaching has measurable and unambiguous standards, procedures and objectives, but for professional practitioners in the artistic field, it emphasizes that empirical facts and data in the teaching process and values are viewed as an integration. The thinking of Sergiovani is consistent with Sahertian. The teaching supervision is the guidance given to teachers based on scientific, democratic, cooperation and constructive principles (Sahertian, 2000: 20). These four principles have an intersection with scientific, clinical and artistic supervision.

There are implicit factors that affect the productivity and performance of a teacher. Understanding the intrinsic factors that exist in a teacher is very difficult. That is not enough to be understood only scientifically. Supervision of instruction, according to Elliot Eisner not only satisfied to get "what" but must get a complete meaning of "what is the meaning". It means that the activity in education is not only seen from the side of ontology (what it is), epistimology (how the process of education) but education must also be seen from axiology (the goal). 
As an illustration of the importance of finding "what" in the above description, it is the standard of passing score for students in national exam. The standard of numbers in this case is understood as "what". To understand why and for what amount of value, there must be a restriction through the approach of meaning. By understanding the meaning contained in numbers, we can get a complete understanding of the values contained in the process and objectives of teaching. Under these circumstances, artistic considerations are needed in developing teaching supervision.

Sergiovani explains what domains in the areas of teaching supervision. Teaching supervision focuses on the classroom. According to him, class is a social system as any other social system that can be viewed as the ownership of three interdependent components, namely theory, structure and technology.

Activity in the classroom during the learning process can be described to the theory study. The theory here is the rules, beliefs and measures that help to understand the empirical reality. In addition to the theoretical components of classroom, learning activities can be seen from the structure perspective. Structure is a set of roles and relationships that arise among members system. And, the last component in the learning process is technology. The technology referred to in this study is a set of techniques and procedures in the learning process. By placing the class as a social system, each component with one component is interdependent. Component of theory in the view of Sergiovani is called as a medium of education, social structure and educational activities. From the above explanation, it can be understood that supervision activities see the class as the domain of activity, not others. The class is a system of social interaction, as the social system in general that involves various interrelated components. Activity in the classroom involves teachers, students in learning activities. This is related to Peter F. Oliva's explanation. According to him, supervision is directed to assist teachers in managing the class. It means the class is understood as a small organization 
of teachers, students, structures and learning processes (Oliva, 1984: 207-234).

The study of teaching supervision Sergiovani is focused on supervision practice theories that integrate various reviews, whether scientific supervision, clinical or artistic supervision. The term theory of practice is rather difficult to grasp. The theory and practice are actually two things that are seen differently in their respective territories. The theory deals with a set of concepts that have regularity of relationships and as its academic foundation. While the practice associated with the procedure or technique to do something that is based on the theory. But Thomas understands the theory of practice is a term that has a unity of meaning. According to him, supervision theory can be seen from four scientific perspectives, first, descriptive science (explaining what happens in class), normative science (explaining what should happen in class), science of interpretation ((explaining the purpose of activity in class) and practice science or practice theory (i.e. what supervisors do in the classroom) The theories that exist in the practice of supervision are to focus on taking actions by the supervisors in improving the learning situation. Fromthe discussion thought ThomasJ. Sergiovani could concluded

1. Theories that exist in the learning process consist of descriptive theory, normative theory, interpretive theory and theory of practice.

2. The theory of supervision practice is the science that focuses on the steps taken by the supervisors to improve the learning process in the classroom.

3. The theory of integrated supervision practice is to see the implementation of supervision from scientific, clinical and artistic review as a comprehensive technical unit in improving the learning process.

4. Fact and meaning is a unity of understanding in the process of learning in the classroom.

5. The empirical reality in the classroom as well as the learning norms must be interpreted carefully, so the normative of 
learning is not rigid and meaningless. Understanding and interpreting the activities of the learning process is very helpful to find a way out of learning problems.

6. Class is a social system consisting of components of theory, structure and technology that are the focus of examination by supervisorsKelas adalah sistem sosial yang terdiri dari komponen teori, struktur dan teknologi yang merupakan fokus pemeriksaan oleh para supervisor

\section{Madrasah Aliyah Based On Pesantren}

For background of Socio-cultural-historical Madrasah and Pesantren , Historically pesantren educational institutions are a form of the oldest community of religious learning institution in Indonesia. This institution was emerged along with the history of the beginning of Islam to Indonesia. The name of pesantren appears in different regions according to regional terms and languages, such as meunasah (in Aceh), surau (in Minagkabau), cottages (in Kalimantan and Riau), and pesantren (in Java) (Azra, 1997: 55). At first, pesantren is an educational institution which teaches simple knowledge about the procedure of practicing the Islamic teachings. Materials presented are such as how to pray and read the holy book of the Qur'an (Steenbrink, 1974: 10). Subsequently, in subsequent developments, the basic materials taught in peasantren have developed into academic study materials, such as, studying the thoughts of classical Islamic figures on theology, law, tasawwuf and society (Dhofier, 1994: 28)

In the next development, pesantern or traditional religious educational institution which is developed and has classical religious education institute is madrasah (Djamil, et.al.: 27). This institution develops fast in the first and second decades in responding the classical learning system from the previous Dutch Government. Seeing this rapid madrasah development, in 1946, the government asked this madarasah institution to be included in seven general subjects into the subjects of the madrasah. This step is then followed up again by the Ministry of Religious 
Affairs in the academic year 1958/1959 by introducing Madrasah Compulsory (MWB) as one of the madrasah education system renewal business. Through this program, the madrasah which already meet the standards set was recognized that it has fulfilled its main learning.

In the future, the government through the Ministry of Religion seems to want some steps towards integrating religious education that develops in society but has not received proportional attention, with general education that has been developed since the Dutch colonial era. The milestones of integration (the integration of National Education) actually began with the emergence of a decree of three Ministers (Minister of Religious Affairs, Education and Culture Minister and the Domestic Affair Minister) on 24th March 1975. In this context, a number of dictums considered as strategic steps toward the integration of education, I General provisions of article 1 stated: (1) madrasah referred to in this Joint Decree: educational institutions that make the subjects of Islam as basic subjects are given at least 30\% in addition to general subjects. (2) Madrasah includes three levels: Madrasah Ibtidaiyah or Elementary School, Madrasah Tsanawiyah or Junior High School, and Madrasah Aliyah or Senior High School. Furthermore, in Chapter II, article 2, it is mentioned that the purpose and objective of improving the quality of education in Madrasah is that the general subject level of madrasah reaches the same level with the general school level in the same level, so that: (1) Madrasah diploma have the same value with Public School diploma. (2) Madrasah graduates can go to upper level public schools. (3) Madrasah students can move to public schools on the same level. Regarding the management and guidance stated in Chapter IV Article 4 as follows: (1) Management of Madrasah is conducted by the Minister of Religious Affairs (2) Religious subjects development in Madrasah is conducted by the Minister of Religious Affairs (3) Guidance and supervision of the quality of General Subjects in Madrasah is conducted by the Minister Education and Culture, together with the Ministry of Religious 
Affairs and the Minister of Domestic Affairs (Saleh, 1981: 116-118). Law No. 20 of 2003 on the National Education System, in Section Three of Secondary Education Article 18 paragraph (3) states that "secondary education in the form of High School (SMA), Madrasah (MA), Vocational School (SMK), and Vocational Madrasah ( MAK), or other equivalent forms ". In the explanation, it is stated that the Department of Madrasah consists of Department of Islamic Studies, Language Science, Natural Sciences and Social Sciences. The relationship between pesantren and madrasah can be seen as a historical, institutional and cultural relation. Historically, the madrasah education system was existed after the existence of pesantren educational institutions. The pattern of education in pesantren requires the existence of boarding house to accommodate santri who are studying. Staying in a dorm is said to be nyantri in a boarding school. The intensity of a person as a consequence of living in a dorm is not only related to the learning pattern of the materials to be taught, but nyantri and stay in the dormitory on the other side as part of the process of character building and the personality of the santri. This dormitory learning system was later developed by various colleges with the aim for the intensity and effectiveness of learning. Finally, this dormitory system led some madrasah which do not have boarding school before are established by the boarding students who are in pesantren as the pattern of education and culture as pesantren.

Madrasah of pesantren cultures see madrasah as a formal learning institution in the context of learning culture in the context of pesantren. Madrasah based on the culture of pesantren requires the location of madrasah building and the santri dormitory in one complex, and the teacher or kyai live around madrasah. Foundation, madrasah and pesantren are in an organizational structure or in a management structure.

\section{Supervision Teaching Models}

Four models known in the supervision of teaching, namely conventional, scientific, clinical, and artistic supervision are 
more effective when all four models of supervision are seen as integral and inseparable. This holistic supervision models for the characters of the ustazd either the Kyai Sepuh and the ustazd who teach have various characters. Ustazd or teacher as Kyai with centralized culture would be more appropriate with the dominant artistic model. This artistic model puts supervisor or principal or senior teacher with a teacher who supervised would feel more comfortable in an atmosphere of friendship and relatives. But in friendship, then supervisor loses framework duties as supervisor. Secretly, with a model of scientific supervision, supervisors have collected some data about the problems that become obstacles in learning.

Models of supervision by the dominance of conventional models would be more appropriately applied to the young teachers. But it is problematic because of culture adherence to the clerics and senior teachers. The advanced new young teachers who have not been experienced in teaching will be more effectively approached by supervisors as if their evaluators looking for flaws and shortcomings young teacher then instructed the young teachers to improve learning in class. Supervisors should be able to tune the rhythm of the model that suits the character of teachers and character issues being addressed.

Supervisor at Islamic senior high schools must not be the principal but teachers who are able and have seniority at the school. Seniority at the school boarding cultural background determines the given role. The problems faced by the teachers need to be identified and made categories and levels. If problems faced by teachers are too complicated, maybe the dominance of the model or clinical supervision would be more appropriate. The same problem faced by the teachers at the school can have problem solving with a different model of supervision. Ethical code or regulation in boarding schools should be rigorously upheld high by supervisors. So that the values that sustain a culture schools that still characterize the communication model at the school with their supervision does not become damaged. 


\section{Perspective Approach in Supervision}

There are three approaches are known in educational supervision, namely the direct approach, the indirect approach and the collaborative approach. The three approaches cannot understand what works and what does not when understanding a separate approach to the character of the problem, the character of the teacher and the socio-cultural context of the school. Madrasah Aliyah or Islamic Senior High Schools boarding with cultural background use three approaches. If we encounter a difficult teacher (mbeling) to be coached, the approach of direct domination will be more effective. Direct approach is based on the principle of behaviouristic psychology. In the indirect supervision approach, supervisors plunge addressing the issues faced by teachers to provide reinforcement. When managing classroom learning well and vice versa, if the teacher who supervised the difficult scouted, alternative administrative punishment is better to grow awareness and consequences as a professional teacher. While senior teachers made up of clerics who lack formal education background but has the authority at the school, then the indirect supervision approach is more dominant. Indirect approach is guided by humanistic psychology. Senior teachers who already have a high awareness about the quality of madrasah but methodologically less mastered, the supervisor simply make a facilitator in the form of people and activities that can improve the performance of senior teachers without offending them. If problematic teachers in madrasah are inconsistent, then collaboratiove approach is more appropriate.

\section{Educational Supervision Technical Perspective}

In the supervision, there are various techniques, namely (1) class visits (2) talks individually (3) groups discussion (4) teaching demonstration (5) classroom visits among teachers (6) curriculum development (7) bulletin supervision (8) professional library (9) workshop and (10) the public school survey. (11) classroom observations (15) inter-visitation (16) selecting a 
variety of materials for teaching and (17) self judging and (18) group interview. While the engineering supervision of the group consists of (a) meeting ( b) having a group discussion (c) heldupgrading and (d) seminars.

From the eighteen techniques above, not all can be applied in Madrasah Aliyah with cultural background. Some of the techniques that are relatively effectively applied are:

a. individual talks; A supervisor can closes the teachers supervised by informal chat or talks while smoking or lunch with the teacher who supervised.

b. group discussion; This group discussion can be facilitated by formal administrative institutions. The form can be seminars, break, or a meeting or a modified form study forum because the study has been a learning culture in the Islamic senior high schools boarding with cultural background.

c. Revitalization of professional library

d. College; The College is a medium of communication among teachers so they can be teachers who teach in the same madrasah or among teachers from different schools. Javanese people say about togetherness Jagong-Jagong Maton . It is so relaxed but productive.

\section{Conclusion}

Based on the discussion above, it can be concluded that supervision of teaching in madarash is a function of leadership communication with pesantren culture so the relationship between teachers with the headmaster or between teachers and students is to follow the pattern of relationship between kyai and santri. Then, supervision approaches with a limited personal relationship approach and in an informal setting are much more effective because supervisory activities between teacher and headmaster are not open. Supervision of teaching uses technique of cultural organization group of religion. And, supervision of teaching uses situational integrated approach. 


\section{References}

Adam, H.F., dan Dickey F.G. 1959. Basic principles of Supervision, New York: American Book Company

Arikunto, Suharsimi. 2004, Dasar-dasar Supervisi, Jakarta: Rineka Cipta.

Azra, Azyumardi. Konstruksi Agama Memasuki Milenium Ketiga, Jurnal PERTA Vol. 1, No. 1, September 1997, DitbinpertaDepag Pusat and PPIM IAIN Jakarta

Bogdan, R.C \& Biklen, S.K. 1982. Riset Kualitatif untuk pendidikan: Pengantar Teori dan Metode: Translated by Munandir. Jakarta PAU, Dirjen Dikti DepDikNas.

Carl, Glickman AD. 1981. Development Supervision (Alternative Practice for Helping Teacher Improve Instruction) Virginia. ASCD

Daryanto. 1998. Administrasi Pendidikan. Jakarta: Rineka Cipta

Depag RI. 1998. Kurikulum Madrasah Aliyah Tahun 1994 : Landasan Program dan Pengembangan, Jakarta : Dirjen Binbaga Islam

1998/1999 Profil Madrasah Aliyah Keagamaan, Jakarta: Dirjen Binbaga Islam,

Djamil, Abdul (dkk). 1999. Pesantren dan Kebudayaan, Kajian Ulang Tentang Peran Pesantren Sebagai Pembentuk Kebudayaan Indonesia, Semarang : IAIN Walisongo

Dhofier, Zamakhsyari. 1994. Tradisi Pesantren -Studi tentang Pandangan Hidup Kyai--, Jakarta: LP3ES

Fajar, A. Malik. 1998. Madrasah dan Tantangan Modernitas, Jakarta: MIZAN

Gwyn, John Minor. 1965. Teory and Practice of Supervision, Doddy, N.Y. Mead and Company

Hadjar, Ibnu. 1999. Dasar-Dasar Metodologi Penelitian Dalam Pendidikan, Jakarta : Raja Grafindo Perkasa 
Horikoshi, Hiroko. 1987 Kyai dan Perubahan Sosial. Jakarta : P3M

Lewis, Arthur J. and A. Miel. 1972. Supervision for instruction. California. Woodworth publishing Company.

Mastuhu. 1994. Dinamika Pendidikan Pesantren. Jakarta : INIS,

Moleong, Lexi J. 1991. Metodologi Penelitian Kualitatif. Bandung : Rosda Karya

Muhadjir, Noeng. 1996 Metodologi Penelitian Kualitatif. Yogyakarta : Rake Sarasih

Presiden RI. (2003) Undang Undang No 20 tahun 2003 tentang Sistem Pendidikan Nasional: Depdiknas Dirjen Dikdasmen

Presiden RI (2005) Undang undang nomor 14 tahun 2005 tentang Guru dan Dosen

Presiden Pemerintah nomor 19 tahun 2005 tentang Standar Nasional Pendidikan

Peraturan Menteri Pendidikan Nasional nomor 16 tahun 2007 Tentang Kualifikasi akademik dan Kompetensi Guru

Peraturan Menteri Pendidikan Nasional nomor 18 tahun 2007 tentang sertifikasi Guru

Raymond H, Harrison. 1968. Supervisory leadership in Education. Van Nostrand Reinhold New York

Sahertian, Piet A. 2000. Konsep Dasar dan Teknik supervisi Pendidikan (dalam Rangka Pengembangan Sumber Daya Manusia, Jakarta: Rineka Cipta

Saleh, Abdurraman. 1981. Penyelenggaraan Madrasah: Peraturan Perundangan. Jakarta: Dharma Bhakti

Steenbrink, Karel A. 1974. Pesantren, Madrasah, Sekolah -Pendidikan Islam dalm Kurun Modern. Jakarta: LP3ES

Sugiyono, 2006. Metode Penelitian Pendidikan. Bandung: Alfabeta

Sutisna, Oteng. 1987. Administrasi Pendidikan Dasar Teoritis untuk Praktek Professional. Bandung: Angkasa 
Supandi. 1986. Administrasi dan Supervisi Pendidikan. Jakarta: Universitas Terbuka Press

Sugiyono. 2005. Memahami Penelitian Kualitatif. Bandung : Alfabeta

Surahmat, Winarno. 1984, Dasar dan Teknik Research, Pengantar Metodologi Ilmiah. Bandung : Tarsito

Syaiful, Sagala. 2000. Administrasi Pendidikan Kontemporer. Bandung: Alfabeta

Van Dersel, William R. 1978. Prinsip dan Teknik Supervisi (Translated by Handoyo). Yogyakarta: Bhatara Karya Aksara 